\title{
Adaptation of the stomatherapy service during the COVID-19 pandemic: an experience report
}

\author{
Adaptação do serviço de estomaterapia durante a \\ pandemia do Covid-19: relato de experiência
}

Adpatación del servicio de estomaterapia durante la pandemia Covid-19: informe de experiência

\author{
Ana Karina Silva da Rocha Tanaka ${ }^{a}$ \\ Rosaura Soares Paczek ${ }^{b, c}$ \\ Bruna Noschang de Brum ${ }^{a}$ \\ Daniela Trintinaia Brito ${ }^{a}$ \\ Elaine Maria Alexandre ${ }^{b}$ \\ Alessandra Garcia de Figueiredo Agostini ${ }^{b}$
}

How to cite this article: Tanaka AKSR, Paczek RS, Brum BN, Brito DT, Alexandre EM, Agostini AGF. Adaptation of the stomatherapy service during the COVID-19 pandemic: an experience report. Rev Gaúcha Enferm. 2021;42(spe):e20200214 doi: https://doi.org/10.1590/19831447.2021.20200214 aniversidade Federal do Rio Grande do Sul (UFRGS). Porto Alegre, Rio Grande do Sul, Brasil.

b Prefeitura Municipal de Porto Alegre. Porto Alegre, Rio Grande do Sul, Brasil.

Hospital de Clínicas de Porto Alegre (HCPA). Porto Alegre, Rio Grande do Sul, Brasil

\section{ABSTRACT}

Objective: To report the experience of adapting the stomatherapy service during the COVID-19 pandemic.

Method: Experience report related to adaptations in the work routine in times of COVID-19 pandemic, from March to May 2020, in a specialized stomatherapy center in a city in the South of Brazil.

Results: The work routines were adapted to suit the protection measures for workers and users who used stomatherapy services. Some assistance processes were implemented to make users' access to care more flexible, and to modify routines to increase the safety of health professionals and users.

Conclusion: The need to adapt the physical area, rethink the dynamics of care, use personal protective equipment, and guidance for servers and patients were of fundamental importance to continue attending the population safely in times of pandemic. Keywords: Coronavirus infections. Primary health care. Pandemics. Public health. Adaptation.

\section{RESUMO}

Objetivo: Relatar a experiência das adaptações do serviço de estomaterapia durante a pandemia do Covid-19.

Método: Relato de experiência relacionado às adaptações na rotina de trabalho em tempos de pandemia do Covid-19, no período de março a maio de 2020 em um centro de referência em estomaterapia de uma cidade da região sul do Brasil.

Resultados: As rotinas de trabalho foram adaptadas para adequar às medidas de proteção para os servidores e usuários que utilizaram os serviços de estomaterapia. Foram implantados alguns processos assistências para a flexibilização do acesso de usuários para atendimento, e modificações de rotinas para 0 aumento da segurança dos profissionais da saúde e usuários.

Conclusão: A necessidade em adequar a área física, repensar a dinâmica do atendimento, uso de equipamentos de proteção individual, orientações para servidores e pacientes foi de fundamental importância para seguir 0 atendimento à população com segurança em tempos de pandemia.

Palavras-chave: Infecções por coronavirus. Atenção Primária à Saúde. Pandemias. Saúde pública. Adaptação.

\section{RESUMEN}

Objetivo: Informar sobre la experiencia de adaptar el servicio de estomatoterapia durante la pandemia de Covid-19.

Método: Informe de experiencia relacionado con adaptaciones en la rutina laboral en tiempos de pandemia de Covid-19, de marzo a mayo de 2020 en un centro de referencia en estomaterapia en una ciudad en la región sur de Brasil.

Resultados: las rutinas de trabajo se adaptaron a las medidas de protección para trabajadores y usuarios que usaban servicios de estomatoterapia. Se implementó algunos procesos de asistencia para que el acceso de los usuarios a la atención fuera más flexible y para modificar las rutinas aumentando la seguridad de los profesionales y usuarios de la salud.

Conclusión: La necesidad de adaptar el área física, repensar la dinámica de la atención, el uso de equipos de protección personal, y las orientaciones para servidores y pacientes fueron de fundamental importancia para continuar ofreciendo el servicio a la población de manera segura en tiempos de pandemia.

Palabras clave: Infecciones por coronavirus. Atención Primaria de Salud. Pandemias. Salud pública. Adaptación. 


\section{口INTRODUCTION}

In December 2019, in the city of Wuhan, China, a pneumonia outbreak emerged and started disseminating throughout the world, being later identified by Chinese scientists as the new coronavirus (COVID-19) $)^{(1)}$. In the beginning of 2020, the World Health Organization (WHO) declared an international Public Health emergency due to the outbreak, this being the highest level ofWHO alerts. In March 11, 2020, COVID-19 was classified as a pandemic ${ }^{(2-3)}$.

Primary Health Care is essential in emergency situations, since knowing the territory, the connection between user and health team, the monitoring of vulnerable families, and the follow up of suspected and light COVID-19 cases are essential to contain the pandemic. It is, therefore, necessary to reorganize the services and the structure of Health Units, according to the characteristics of the epidemic in the territory in which they find themselves ${ }^{(4)}$.

In the current situation of the epidemic in Brazil, the effective execution of isolation in people with suspicious cases and their close contacts is limited due to how fast the virus disseminates and how difficult the cases are to monitor, in addition to the absence of a broad testing system ${ }^{(5)}$.

The infection takes place in the higher respiratory tract through direct contact with infectious respiratory secretions, such as aerosols and droplets from infected people, in addition to contact with contaminated samples, surfaces, or objects. Due to its high pathogenicity, virulence, lethality, persistence, and survival in objects and surfaces, where it may last from five hours to seven days, and its higher stability in plastics and stainless steel than in copper and cardboard, health professionals fear the risk of infection, since there are still no efficient pathogenicity and therapies, and there are doubts about biosafety and the safety of equipment ${ }^{(6)}$.

The lack of personal protective equipment (PPE) and collective protection equipment (CPE) in health services, associated to the high number of cases, contributes for a higher number of health professionals to be infected, and these professionals are three times more likely to contract the virus than other people. In Italy, $8.3 \%$ of people infected are health professionals, and in China, 3.8\% are $^{(7)}$. In Brazil, until May 7, 98 nursing professionals died due to COVID-19, 25 of which were nurses while 56 were nursing technicians and auxiliaries ${ }^{(8)}$.

Those who present symptoms are advised to seek Primary Health Care Units, which may increase the contamination rates of professionals in this field of work, due to the lack of structure and PPEs in the health services ${ }^{(7)}$. Until May 19, Rio Grande do Sul had 3,798 people with confirmed COVID-19 cases in 224 cities, in addition to 160 deaths, a death rate of $4.2 \%\left({ }^{(9)}\right.$

The Specialized in Stomatherapy Center is a service from the City Health Secretariat, which works from Monday to Friday, from 7 a.m. to 4 p.m., attending an average of 1,800 people registered to receive the material needed for ostomies and/or incontinences and to carry nursing consultations and special wound dressings. The service also registers new patients to acquire materials for ostomy and incontinence and dispenses them, attending a daily average of 90 people. It counts on a coloproctologist, three stoma therapy nurses, two nursing technicians, two nursing auxiliaries, one psychologist, one nutritionist, and one social worker. Since this is an essential service, the advent of the pandemic of COVID-19 did not change its working hours, and safety measures were necessary for both users and professionals who work in the service.

Considering this context, this study aims to report the experience of adapting the stomatherapy service during the COVID-19 pandemic, in a specialized center for stomatherapy in a city in the South of Brazil. This is information is relevant, since it may serve as a model for the improvement of other services that continue working during the pandemic.

\section{$\square$ METHOD}

Since this is an experience report about adaptations in the work routine during the COVID-19 pandemic, to attend the biosafety measures in the service, carried out from March to May 2020. Adaptations reported in the work routine of workers in the Specialized Stomatherapy Center of a city in the South region of Brazil, which is a part of the Health Care Network of the city.

The Specialized Stomatherapy Center works from Monday to Friday, from 7 a.m. to 4 p.m., has 9 public workers and receives patients with ostomies, incontinence, and injuries, in addition to registering and dispensing materials for ostomies, diapers, wound dressings, and nursing consultations, attending nearly 1,800 users per month in two offices and one management room for material delivery. The attention takes place according to spontaneous demand for the distribution of ostomy and incontinence materials, and also for new records to be made. The consultations, be them nursing consultations or those with the proctologist and the nutritionist, are previously scheduled, except in urgent cases, in which the patient is attended in extra consultations. 
The wound dressings are also previously scheduled, and in exceptional situations may be changed, when the patient cannot be there in the day scheduled.

The service has three stomatherapy nurses, one nursing technician, three nursing auxiliaries, two administrative auxiliaries, one coloproctologist, one nutritionist, one psychologist, and one social worker. The wound dressing service carries out, on average, 180 wound dressings and 143 material deliveries for user every month, in addition to being the reference for 26 other health units in the city. It has 621 patients registered for the acquisition of materials, such as collectors and adjuvant materials, 730 patients registered to receive diapers, with a monthly average of 100 nursing consultations.

The nursing consultations are scheduled via an information system from the City Health Secretariat, and according to the demands of the day. Material for ostomies and diapers is dispensed monthly, according to spontaneous demand, and materials for wound dressing are dispensed according to the needs of the user. These consultations could not be suspended, since this is an essential service. However, for patients who systematically came to the center only to exchange their bag, and who did not show any stoma or peristomal skin, it was requested that some family member would make the exchange, to avoid them from moving throughout the city and to reduce the number of patients within the service. Concerning the dressings, patients were offered materials to dress the wounds themselves, to avoid leaving their house.

The administration of the sector was in agreement with the measures taken.

\section{RESULTS AND DISCUSSION}

Due to the large number of people attended daily in the stomatherapy service, the work routine was adapted during the COVID-19 pandemic, to adapt to protective measures, guaranteeing the safety of workers and users of the service. In the beginning of the pandemic, disposable masks were provided for the use of all workers. Symptomatic users were given masks at the entrance of the building.

Facial protectors were found to be a good protective strategy, and were, initially, handcrafted by the workers themselves, who also sought donations of these equipment from companies, to guarantee the safety of the professionals. The equipment was later provided by management, in addition to an amount donated by the union of the workers. Acrylic protective equipment was adapted in the desks where the public was received, to increase the protection of workers and users.
The windows of the building were kept open, guaranteeing that the environment remained ventilated, and the air conditioner was kept turned off during the work shift. Adornments such as: earrings, watches, rings, bracelets, and nametags hanging from cords were avoided, to reduce the chance of contamination of the professionals. Due to the large number of people attended daily, disposable numbers started to be used, being distributed at the entrance of the building to control access, allowing a maximum of five people at a time, avoiding agglomeration at the reception.

Furthermore, certain chairs were isolated using tape for people not to sit side-by-side. We advised all users who arrived at the service to clean their hands with alcohol gel, which was made available in an auxiliary table at reception, and also offered daily advice on the adequate use of masks and gloves for patients and relatives.

The dispensation of ostomy bags and adjuvant equipment was made more flexible, and relatives could now reclaim these, in addition to those already registered in the system. Even delivery services were allowed to reclaim the materials, as long as they identified themselves or presented some document, written or sent through message applications, that proved the patient requested them to receive the medication for them. We requested the patients who sought the service only to replace their bags to carry out these exchanges, whenever possible, at home, with the help of relatives or caregivers, to diminish their numbers in the service.

The confection of the stoma may be temporary or permanent, bringing several psychosocial effects that impair social, family, and work life. Therefore, it is important for specialized health services to attend patients aiming to promote health and encourage self-care, to prevent complications and offer ostomy bags and adjuvant equipment. The ostomy bag is used to store their intestinal or urinary evacuations ${ }^{(10)}$.

We maintained the consultations of patients who presented peristomal skin injuries and those who could not replace their ostomy bag by themselves. We also answered questions about material delivery, consult scheduling, and offered advice, via phone and through message applications. The first consultations were not blocked because these patients needed to be attended to receive guidance and evaluate which bag should be used.

Regarding wound dressing, at first, the initial consultations were blocked, since we believed that the patient should be preserved. The service, after all, already has an expressive number of people, and this would prevent crowding the waiting room. For patients who were already 
in follow up and who, a nurse believed, were capable of dressing the wound at home, the consultations became less frequent with no damage to the treatment. A larger number of materials was made available to be brought home and, if necessary, patients could get in touch via telephone to clarify any doubts.

The times in which patients could come were made more flexible, due to difficulties with public transportation. In some cases, we have tried to share the assistance with the Primary Health Care Unit that sent the patient originally, monitoring periodically and providing materials for the care to be continued. The use of PPEs increased, including facial protectors, surgical masks and N95, gloves, liquid alcohol, gel alcohol, and general disinfectants, since cleaning became more frequent.

The stomatherapy service kept its weekly team meetings despite the distancing, in different hours of the day to avoid crowding. As a result, the administrative functions and the regular functioning of the service were guaranteed through the offering of psychological support to the workers, who received guidance about the adequate use of the PPE and about changes in their work routines. Suggestion from the workers themselves were accepted, according to the possibilities of the service, and there were attempts to reduce the stress the situation caused on all workers.

The lack of scientific knowledge about the new coronavirus, combined with its fast dissemination and lethality, brings uncertainty about what would be the best strategies to use when confronting the pandemic ${ }^{(5)}$. Little is discussed about the conditions and the best ways to organize health services, since the greatest challenges to these institutions is to reorganize attention, provide quality PPEs in an adequate amount, and train professionals to work while dealing with this new situation ${ }^{(11-12)}$.

The adoption of the set of standard precaution measures (SPM) is an effective way to reduce the risks to which health professionals are exposed. These measures include: hand hygiene, immunization, use of personal protective equipment, collective protection equipment, and appropriate management of residues in the services. These measures are recommended for all procedures carried out by health professionals, to avoid the dissemination of microorganisms, since their non-use, or the inadequate use of the SPMs, increases the risk of infections ${ }^{(13)}$. All precaution measures adopted in the service follow the guidance of the
National Health Surveillance Agency and from the State Health Secretariat ${ }^{(14-15)}$.

Positive attitudes have the role of facilitating the implementation of changes which, when carried out properly, coherently, and with good communication, make it easier for the workers to accept, adhere to, and be committed to these changes, generating better results ${ }^{(16)}$.

In this period, four workers were on leave: one physician, two administrative auxiliaries, and one nursing auxiliary. Three of them were on leave due to being of a risk group, while another was already undergoing health treatment since the year started. The physician worked remotely, via phone and messaging application, discussing the cases, therapeutic conducts, and referrals with the nurse. One administrative aid also worked remotely in this period, calls being diverted to their phone so they could answer them. Therefore, two workers from other sectors had to be reassigned to this service, for material delivery and administrative duties. The adaptations to the changes carried out in the service followed the norms and guidance from the WHO, the City Health Secretariat, and the District Management.

\section{CONCLUSION}

The adaptation of the physical area, the use of PPEs, and the guidance for workers and patients were paramount for the attention to continue. The adaptations in the routine of the service were discussed with all workers and collaborators involved, and suggestions emerged that showed their interest in participating in the activities. All adaptations carried out for the functioning of the service were well accepted and followed uniformly by the entire team, and also by the users who understood the need for these changes.

The limitation of this study was the fact that it is an experience report from a single health service, in which the time for implementing the changes was limited and the satisfaction of users and professionals with the measures was not evaluated, neither was its positive impact for the control of the pandemic. However, the experience was positive, since the discussion of the measures implemented, as well as the adherence and participation of the entire team, led to more safety, diminishing the risks of exposing professionals as they carried out their daily tasks in the stomatherapy service. 


\section{REFERENCES}

1. Wang C, Horby PW, Hayden FG, Gao GF. A novel coronavirus outbreak of global health concern. The Lancet. 2020; 395 (10223):470-3. doi: https://doi. org/10.1016/S01406736(20)30185-9

2. Organização Pan-Americana de Saúde (BR). Brasília, DF: OPAS; c2020 [cited 2020 May 19]. Folha informativa - COVID-19; [about 1 screen]. Available from: https://www.paho.org/bra/index.php?option=com_ content\&view=article\&id=6101: covid1 9\&ltemid $=875$

3. Oliveira LCMA. Information about the new coronavirus disease (COVID-19) [editorial]. Radiol Bras. 2020;53(2):V-VI. doi: https://doi. org/10.1590/0100-3984.2020.53.2e1

4. Dias ST, Serra LW, Ferreira FL, Coelho AAPS. What is the role of Primary Health Care in the COVID-19 pandemic? Epidemiol Serv Saúde. 2020;29(2):e2020166. doi: https://doi.org/10.5123/s1679-49742020000200024

5. Werneck GL, Carvalho MS. The COVID-19 pandemic in Brazil: chronicle of a health crisis foretold. Cad Saúde Pública. 2020;36(5):e00068820. doi: https:// doi.org/10.1590/0102-311X00068820

6. Binsfeld PC, Colonello NA. Coronavírus - SARS-CoV-2: Classe de risco e consensos de biossegurança para laboratório com amostras infectantes. SciELO Preprints 399 [Preprint]. 2020 [cited 2020 May 20]. Available from: https://preprints. scielo.org/index.php/scielo/preprint/view/399. doi: https://doi.org/10.1590/ SciELOPreprints.399

7. Ribas FAR, Marcelo N, Rita DM. Assessing the severity of COVID-19. Epidemiol Serv Saúde. 2020;29(2):e2020119. doi: https://doi.org/10.5123/ s1679-49742020000200008

8. Conselho Federal de Enfermagem (BR). Brasília, DF: Cofen; c2020 [cited 2020 May 22]. Brasil ultrapassa EUA em mortes de profissionais de Enfermagem por Covid-19; [about 1 screen]. Available from: http://www.cofen.gov.br/ brasil-ultrapassa-eua-em-mortes-deprofissionais-de-enfermagem-porcovid-19_79624.html
9. Secretaria Estadual da Saúde (RS). SES-RS: Covid19. [Internet]. [cited 2020 May 21]. Available from: http://ti.saude.rs.gov.br/covid19/

10. Mareco AMP, Pina SM, Farias FC, Name KPO. A importância do enfermeiro na assistência de pacientes com estomias intestinais. ReBIS: Rev Bras Interdic Saúde. 2019 [cited 2020 May 19];1(2):19-23. Available from: http://revista. rebis.com.br/index.php/rebis/article/view/136/60

11. Jackson FJM, Ávila AA, Eduardo A, Garcia GE, Akiyoshi SC, Maria M. A saúde do trabalhador e o enfrentamento da COVID-19. Rev Bras Saúde Ocup. 2020;45:e14. doi: https://doi.org/10.1590/2317-6369ed0000120

12. Servolo MEA. Health professionals ght against COVID-19 [editorial]. Acta Paul Enferm. 2020;33:e-EDT20200003. doi: https://doi.org/10.37689/ acta-ape/2020edt0003

13. Souza FF, Sousa IA, Oliveira LMN. A utilização de equipamentos de proteção individual e coletiva por profissionais de saúde: revisão integrativa. Rev Aten Saúde. 2018;16(58):102-8. doi: https://doi.org/10.13037/ras. vol16n58.5667

14. Brazil. Ministério da Saúde. Agência Nacional deVigilância Sanitária. Nota Técnica GVIMS/GGTES/ANVISA No 04/2020. Brasília, DF: Anvisa; 2020 [cited 2020 0ct 31]. Available from: https://www20.anvisa.gov.br/segurancadopaciente/ index.php/alertas/item/covid-19

15. Secretaria Estadual da Saúde (RS). Plano de Contingência e Ação Estadual do Rio Grande do Sul para Infecção Humana COVID-19. Versão 5. Porto Alegre; 2020 [cited 2020 May 22]. Available from: https://saude.rs.gov.br/upload/ arquivos/202002/21152837-plano-deacao-corona-2020-rs-versao-5-2102. pdf

16. Machado LCP, Neiva ER. Práticas de gestão da mudança: impacto nas atitudes e nos resultados percebidos. Revi Psicol Organ Trab. 2017;17(1):22-9. https://doi. org/10.17652/rpot/2017.1.12157 


\section{- Authorship contributions:}

Conception - Ana Karina Silva da Rocha Tanaka, Rosaura Soares Paczek, Bruna Noschang de Brum, Daniela Trintinaia Brito.

Investigation - Ana Karina Silva da Rocha Tanaka, Rosaura Soares Paczek, Bruna Noschang de Brum, Daniela Trintinaia Brito.

Methodology - Ana Karina Silva da Rocha Tanaka, Rosaura Soares Paczek, Bruna Noschang de Brum, Daniela Trintinaia Brito.

Supervision - Ana Karina Silva da Rocha Tanaka, Rosaura Soares Paczek.

Validation - Ana Karina Silva da Rocha Tanaka, Rosaura Soares Paczek, Bruna Noschang de Brum, Daniela Trintinaia Brito, Elaine Maria Alexandre, Alessandra Garcia de Figueiredo Agostini.

Visualization - Ana Karina Silva da Rocha Tanaka, Rosaura Soares Paczek, Bruna Noschang de Brum, Daniela Trintinaia Brito, Elaine Maria Alexandre, Alessandra Garcia de Figueiredo Agostini.

Writing - original draft - Ana Karina Silva da Rocha Tanaka, Rosaura Soares Paczek, Bruna Noschang de Brum, Daniela Trintinaia Brito, Elaine Maria Alexandre, Alessandra Garcia de Figueiredo Agostini.

Writing - review and editing - Ana Karina Silva da Rocha Tanaka, Rosaura Soares Paczek, Bruna Noschang de Brum, Daniela Trintinaia Brito, Elaine Maria Alexandre, Alessandra Garcia de Figueiredo Agostini.

\section{- Corresponding author:}

Ana Karina Silva da Rocha Tanaka

Email: anakarinatanaka@gmail.com

\section{Associate editor:}

Dagmar Elaine Kaiser 